\title{
Intake of the "Chahuis" Bedbug Thasus Gigas Burn (Xamues) By Diabetic Patients for Glucose Control.
}

\author{
${ }^{1}$ Zamora López María Del Carmen, ${ }^{1}$ Jiménez Pérez Adriana Jocelyn, ${ }^{1}$ Castillo \\ Sandoval Adriana, ${ }^{1}$ García García Michel Alejandro, ${ }^{1}$ Canales Martínez María \\ Eloísa, ${ }^{* 2}$ Ruvalcaba Ledezma Jesús Carlos \\ ${ }^{1}$ Students of Medicine in (ICSA-UAEH) Institute of Health Sciences, Hidalgo State University. Pachuca City, \\ Hidalgo State, Mexico. ${ }^{* 2}$ Research Professor in (ICSA-UAEH) Institute of Health Sciences, Hidalgo State \\ University. Pachuca City, Hidalgo State, Mexico
}

\begin{abstract}
Objective: To determine whether the intake of chahuis or Xamues bedbug has favorable effects on glucose control in people with type II diabetes.

Methods: An exploratory cross-sectional study was conducted through the application of a survey among 58 randomly selected people in the municipality of Actopan, Hidalgo, Mexico.

Results: All the participant 100\% knew about the bug, 95\% eat the bedbug, 25\% of the studied sample had diabetes, of which $14 \%$ ate the insect as an option to control their blood glucose, thus neglecting their medical treatment. Most of the respondents were seniors; the educational level in most of the respondents is Elementary (62\%).

Conclusions: Consumption of Xamues in this population is not only associated with a likely positive impact on glucose control but are associated other therapeutic properties, such as the exquisite taste shown in the preparation of various typical dishes of this region.
\end{abstract}

KEY WORDS. Type II Diabetes, Thasus gigas, detachment, glucose control, therapeutic.

\section{INTRODUCTION}

Diabetes mellitus is a disease that occurs when there is an excess of glucose in the plasma, qualitative and quantitative abnormalities of carbohydrate and lipid metabolism, characteristic pathological changes in nerves and small blood vessels, and intensification of aterosclerosis. [1,2] Of the 3\% to $4 \%$ of the general population known to be affected $90 \%$ have non-insulin dependent diabetes, of whom $60 \%$ to $90 \%$ are obese. Obesity, a common precursor of type II diabetes mellitus, is associated with insulin resistance. [3]Genetic and molecular basis of type 2 diabetes are still poorly defined. NIDDM is caused by a disorder of insulin secretion and resistance to the action of this. Normally, the basal secretion of insulin follows a rhythmic pattern, which is interrupted by the response to a glucose load. [4-6] The insulin receptor is a membrane glycoprotein composed of two $\alpha$ subunits and two $\beta$ subunits. The insulin-receptor complex is internalized and, in insulin-dependentcells (muscle and adipose tissue), increases the number of glucose transporters (GLUT4) by translocation of these from the intracellular locus to the plasmatic membrane. Receptor degradation is carried out by fusion with lysosomes. Degradation accelerates when circulating insulin levels are high and thus, are reduced in number. This is called insulin resistance. [7]

The highest hospital morbidity rate in 2010 for non-insulin dependent (Type II) diabetes in the population between 75 to 79 years, affected 701 out of 100, 000. Obesity is among the main risk factors that increases chance of developing diabetes. In accordance with the Panamerican Health Organization (2012), in America between "7\% and $12 \%$ of children under 5 years and a fifth of adolescents are obese, while adults are close to $60 \%$ ", so it is important to generate attention policies to reduce obesity in the Mexican population. Globally, diabetes during 2011 caused the death of 4.6 million people in Latin America and represents $12.3 \%$ of total deaths (IDF, 2011). [8-12] In Mexico, the highest observed mortality rate in 2010 by diabetes is presented in the Federal District (104 cases out of 100000 inhabitants). In 2010 as a result of Type II diabetes (non-insulin dependent), 45 die out of 100 thousand people, while only one person died due to Type I diabetes (insulin dependent). [13] 
Hidalgo has a population of 2,231,000 inhabitants, occupies the 18th place of diabetic patients nationally. The estimated prevalence of diabetes in this state (ENSA 2000) is 6.9\%, ranking the 30th place nationally. The estimated number of patients with diabetes is of $45,800(20.5 \%)$. [14,15]

\section{GENERAL CHARACTERISTICS OF Thasus gigas Burn?}

They are a species of insects that can be find in semiarid zones as it is the Valley of the Mezquital, in the state of Hidalgo Mexico, where they grow in the mezquites feeding of the most tender leaves and green stems. It belongs to the Coreidae which are the most abundant and with larger geographical distribution. The first adults appear in June and August, the percentage of adults is mostly from May until September. These insects can be consumed within a big diversity of typical foods, among them are the sauces, and one of so many types of sauce is the traditional one of the Valley of the Mezquital where the principal ingredient is the insect of the mezquite "Xamues" (Thasus gigas burn) in combination with the chili. [16] To use the bug Thasus gigas for the development and conservation of a traditional sauce the Valley the Mezquital, chemical analysis was made proximal to the bugs, an important source of animal protein. [17] Popular knowledge the consuming points for diabetes, but no known publications about. There have been few studies on the importance of this type of insects, but in other aspects it has only considered only the nutritional and anatomical facts. $[17,18]$ The popular or empirical knowledge of these insects is scientifically important to investigate its effect on people with type 2 diabetes mellitus. This I pecially important due to the fact that some people have stopped taking their medications and taking those insects I temporary, also resemble triatomins situation could confuse intake, some people find that if they eat enough may have fever; therefore, this type of research is important. This study opens the door to other studies where glucose levels were measured after the intake of these insects during certain seasons by diabetic people.

\begin{tabular}{ll}
\hline Thumbtacks: & Thasus gigas \\
\hline Family: & Coreidae \\
Gender: & Thasus \\
Specific epithet: & gigas \\
Common name: & Xamues \\
\hline
\end{tabular}

Taxonomy of the Insects Xamues Thasus gigas [17]

\section{METHODS}

An exploratory cross-sectional study in which 58 people of the municipality of Actopan, Hidalgo were interviewed. To know about chahuis consumption and its Relationshipship to diabetes. The municipality of Actopan has a population of 54,299 inhabitants [19] of which is unknown exactly how many people have the disease. The selection of respondents was random in both sexes, people between 28 and 85 years old and excluding only those people who had no knowledge of the bedbug. The study was realized to random people as this was possible to obtain different information about the features, their use in medicinal remedies, cooking techniques and the knowledge degree in this population.

\section{$>$ Variables analyzed}

- Gender, age, marital status and educational level.

- Suffering from type II Diabetes mellitus, time he has had the disease and if there is an appropriate medical treatment.

- Knowledge and chahuis consumption and knowledge about the bedbug that causes Chagas disease.

- Consumption purpose, how people feel after eating and if there are suspension of medical treatment.

- Taste and consumption frequency

- Initial and final glucose level.

$>$ Statistical analysis

All variables were analyzed individually in a database in SPSS -2 .

\section{RESULTS}

58 people between 28 and 85 years old were surveyed. Were 10 men (17\%) and 48 women (83\%). All respondents know the chahuis and $95 \%$ to consume them, so we know that effectively in the majority of the population to know and use them for different reasons. In (Table 1), the consumption purpose of the bedbug is shown, the majority of the population, $78 \%$ agree that their consumption is by pleasure, $8 \%$ is as remedy for 
different diseases such as type II diabetes mellitus, cough, thyroid gland diseases and the remaining $2 \%$ think that their consumption is by whim, family custom and because it is possible that it contains iodine, whence is mentioned above, which is consumed to regulate the function of the thyroid gland for proper operation and production of its two main hormones T3 (triiodothyronine) and T4 (thyroxin) needs iodine. To form the normal amount of thyroxin 50 milligrams of iodine are required annually, about which joins the tyrosine turning it into monoyodotirosinas and diyodotirosinas and then in the following minutes or hours iodotyrosines residues are coupled to form T3 and T4 hormones. Only 15 people (26\%) of the 58 surveyed have type II diabetes mellitus and these 15 people eat the chahuis bedbug for glucose control, of which 4 people $(7 \%)$ have suspended their medicines by chahuis consumption, expressing that their consumption cause well-being (Table 2) and only one of them does not go to medical appointments and the other 14 do it regularly.Finally, 52\% think that the taste of chahuis is excellent and only $2 \%$ think the opposite, so its consumption is raised in Actopan population.

It also refers to the total number of people who know the bedbug that causes Chagas disease; (Table 3) shows that $22 \%$ know the bedbug that causes the disease; however $78 \%$ of this population does not know the bedbug, which could be a risk factor for the population because the bedbug has similar characteristics to the Xamuie bedbug.By analyzing and comparing the data we can also realize that education level is very important to relate and see the impact it has on people with diabetes. In (Table 4) more information about this Relationshipship is shown.In (Table 5) we note that of the 15 people with diabetes and who consume the bedbug only 4 have suspended their medications, which is a problem because we really still not known the true effects that could have the chahuis consumption and could represent risk to all those people who decide to leave their treatment due to they feel well, which on the other hand also relates to education level, which is reflected in bad decisions that sometimes people make but because of having low education.

\begin{tabular}{|l|l|r|r|r|r|r|}
\hline \multicolumn{2}{|c|}{ Table 1. Reason for consuming Chahuis bedbug. } \\
\hline \multicolumn{2}{|c|}{ Reason consumption } & Frequency & Percentage & Valid percentage & Accumulated percentage \\
\hline Valid & Whim & 45 & 77.6 & 81.8 & 81.8 \\
\hline & Remedy & 8 & 13.8 & 14.5 & 96.4 \\
\hline & Other & 2 & 3.4 & 3.6 & 100.0 \\
\hline & Total & 55 & 94.8 & 100.0 & \\
\hline Missing data & System & 3 & 5.2 & & \\
\hline Total & & 58 & 100.0 & \\
\hline
\end{tabular}

\begin{tabular}{|c|c|c|c|c|c|}
\hline \multicolumn{2}{|c|}{ How does people feel. } & Frequency & Percentage & Valid Percentage & $\begin{array}{l}\text { Accumulated } \\
\text { Percentage }\end{array}$ \\
\hline \multirow[t]{5}{*}{ Valid } & Normal & 29 & 50.0 & 52.7 & 52.7 \\
\hline & Well & 20 & 34.5 & 36.4 & 89.1 \\
\hline & Bad & 1 & 1.7 & 1.8 & 90.9 \\
\hline & Other & 5 & 8.6 & 9.1 & 100.0 \\
\hline & Total & 55 & 94.8 & 100.0 & \\
\hline $\begin{array}{l}\text { Missing } \\
\text { data }\end{array}$ & System & 3 & 5.2 & & \\
\hline Total & & 58 & 100.0 & & \\
\hline
\end{tabular}

\begin{tabular}{|l|r|r|r|r|r|}
\hline \multicolumn{5}{|c|}{ Table 3. Percentage of people who know the bedbug that causes Chagas disease. } \\
\hline \multicolumn{2}{|c|}{ You know them } & Frequency & Percentage & Valid Percentage & Accumulated Percentage \\
\hline Valid & Yes & 13 & 22.4 & 22.4 & 22.4 \\
\hline & No & & & 77.6 & 100.0 \\
\hline
\end{tabular}




\begin{tabular}{|c|c|c|c|c|c|}
\hline & & \multicolumn{4}{|c|}{ EDUCATIONAL LEVEL } \\
\hline & & Frequency & Percentage & Valid Percentage & $\begin{array}{l}\text { Accumulated } \\
\text { Percentage }\end{array}$ \\
\hline \multirow{6}{*}{ 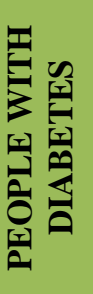 } & $\begin{array}{c}\text { Elementary } \\
\text { School }\end{array}$ & 36 & 13.8 & 13.8 & 13.8 \\
\hline & High school & 10 & 62.1 & 62.1 & 75.9 \\
\hline & & 15 & 25.9 & 25.9 & 25.9 \\
\hline & Preparatory & 3 & 17.2 & 17.2 & 93.1 \\
\hline & University & 1 & 5.2 & 5.2 & 98.3 \\
\hline & Not studied & 8 & 1.7 & 1.7 & 100.0 \\
\hline
\end{tabular}

Table 5. Relationship between Chahuis consumption and the medicines suspension.

\begin{tabular}{|c|c|c|c|c|c|}
\hline & & Frequency & Percentage & Valid Percentage & $\begin{array}{l}\text { Accumulated } \\
\text { Percentage }\end{array}$ \\
\hline \multirow[b]{2}{*}{ 胥 } & Yes & 55 & 94.8 & 94.8 & 94.8 \\
\hline & No & 3 & 5.2 & 5.2 & 100 \\
\hline \multirow{2}{*}{ 莺 } & Yes & 4 & 6.9 & 28.6 & 28.6 \\
\hline & No & 11 & 17.2 & 71.4 & 100.0 \\
\hline
\end{tabular}

\begin{tabular}{|c|c|c|c|c|}
\hline \multicolumn{4}{|c|}{ Table 6. Glucose levels measurement of people with diabetes. } \\
\hline & Minimum & Maximum & Average & $\begin{array}{c}\text { Standard } \\
\text { deviation }\end{array}$ \\
\hline Initial glucose level & 250.0 & 350.0 & 293.333 & 51.3160 \\
\hline Final glucose level & 110.0 & 180.0 & 143.333 & 35.1188 \\
\hline
\end{tabular}

Figure 1. Shows the educational level of the population in Actopan Hidalgo, Mexico

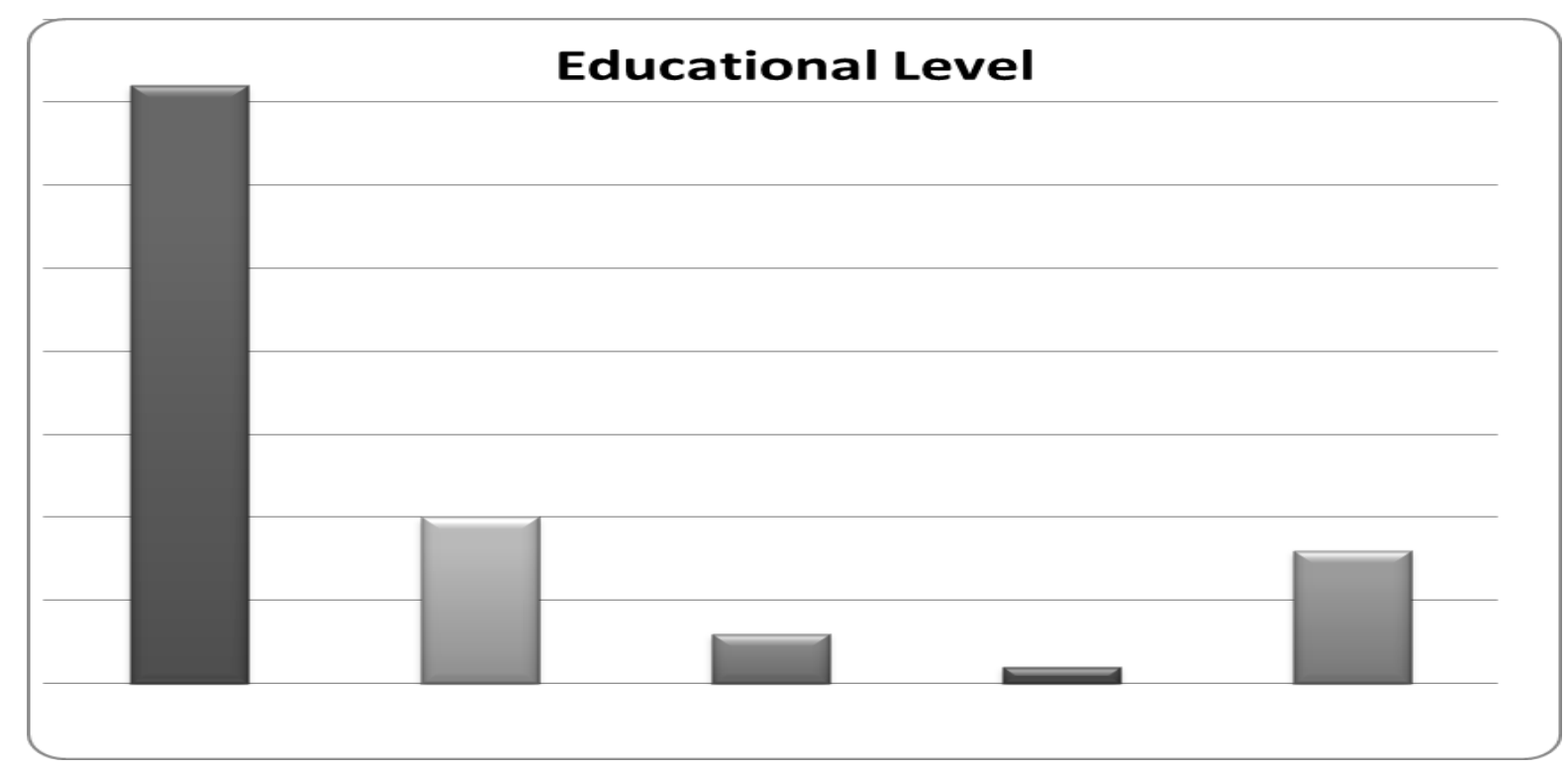


Figure 2. Photographs of the Thasus gigas BURN (XAMUES). [20]

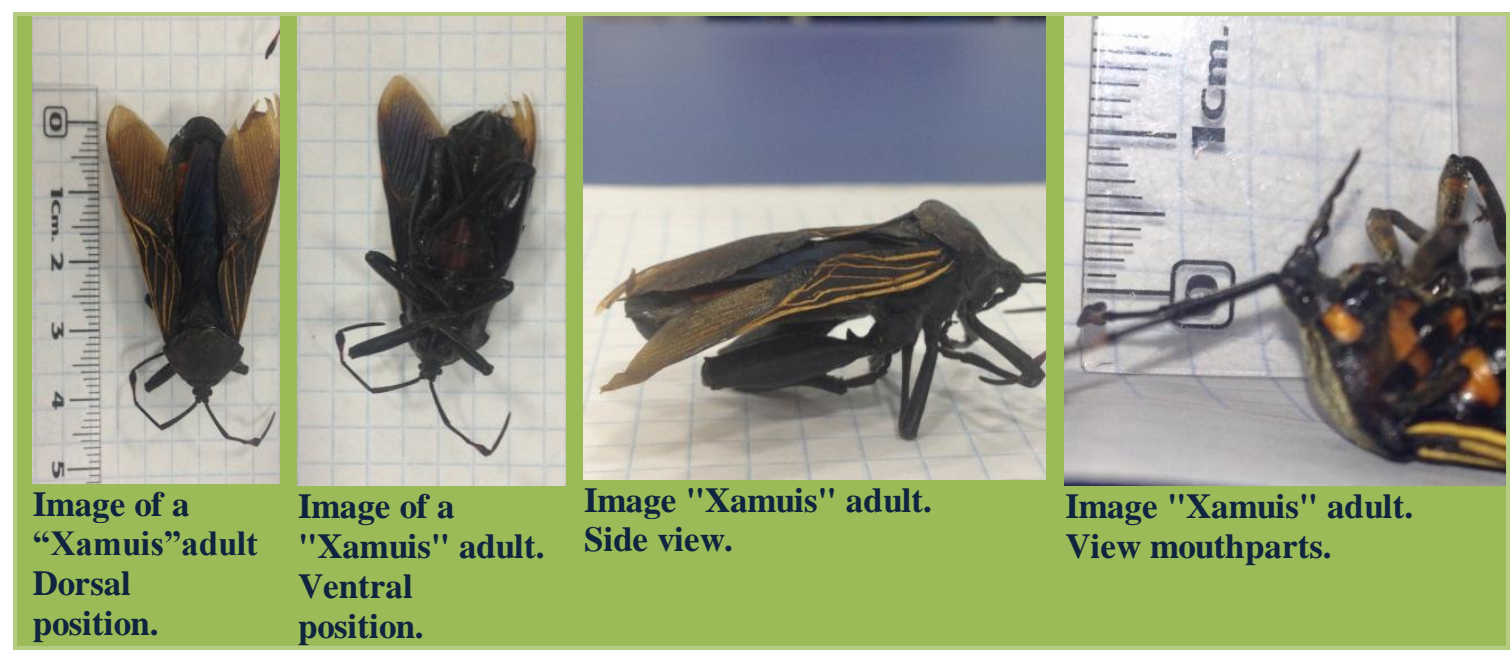

\section{DISCUSSION}

This study was realized with the intent of collect as much information as possible regarding the intake of this insect by adults in Actopan, Hidalgo, bacause it is common to find that this insect is sold in the market everyday when is season. Insect anatomy, especially when it is in nymphal stage, or when it is small keeps a similarity to triatomos transmitters of Chagas disease, especially the point that it can be a treatment for type II diabetes, this encourages to seek useful information that in the future will help for future research work, where control is taken in glucose levels measurements to evaluate this effect in a forceful way (Table 6). Another key aspect is their comments about this insect has the generation of iodine in their secretions, population says the bedbug has a thick bright yellow liquid, which once in contact with skin is difficult to erase its color, so, they explain that use various techniques, such as putting them in water or put them in salt before consumption, because the "acid" as they call it contains substances that may be irritating to the time to consume them and it is possible that this is the substance that contains the iodine mentioned. Moreover, it is also stated that people use it for bronchitis or cough, commenting that the results are quite satisfactory, but most people know that their consumption is for glucose control, so many people in the bedbugs season between July and September go out looking for insects in mesquite trees, trees where they live and breed.However, when analyzing the data it was observed that there are certain risks and the fact that most of the population (78\%) do not know the bedbug that causes Chagas disease, so it is thought that the population is at risk and that collection of chahuis is carry out without any safety measures, just they trust that all bedbugs found in the mesquite are chahuis, their anatomy could be confused with triatomos, some people say it is not like those vectors, but ignorance to collect them could represent health risks, because when chahuis are small have more similarity to these and confusion could be more likely. Moreover, the educational level of this population is very elementary, 64\% studied only the primary and the majority without finish it, so we can see that influence in the fact that the population with diabetes suspend their medications and gives little importance to their health, just for the fact that at that time does not have unease.Finally it was verified that if definitely the population claims to find improvement, consuming chahuis and its consumption is associated not only diabetes but also other diseases, whence opens the door to performing various research projects where the results of this research may be a antecedent in terms of therapeutic-pharmacological, because even are used in the preparation of sauces or other typical dishes of this region, do not lose sight that these could represent a delicious option for chronic disease control, such as type II diabetes mellitus.

\section{CONCLUSIONS}

The information obtained from the respondents speech allows us to propose the idea of the possible influence of chahuis bedbug in the pharmacological treatment of type II diabetes, and this opens the possibility to continue researching based on the glucose levels measurement to seek infer the effect of the intake of these insects in this disease, because apparently it has been published only from the culinary aspect rather than therapeutics that could represent for type II diabetes mellitus.7\% of people with type II diabetes mellitus in his speech say have lost attachment in your medical treatment for diabetes control; this confers the emergency to realize glucose measurements in people of this population, who eat the chahuis bedbug with or without medical treatment for type II Diabetes Mellitus. Therefore this dish would be besides a cultural tradition an option for well-being population. 


\section{ACKNOWLEDGMENT}

The authors of the present research article would like to acknowledge and truly thank the collaboration of Yesenia Elizabeth Ruvalcaba Cobián who has a B.A in Teaching English as a Foreign Language, for her contributions on the revision and translation of the article; situation which allows the possibility to increase the transferring and modification of scientific knowledge.

The authors declare that no conflict of interests for the publication of this research paper.

\section{REFERENCES.}

[1] West KM: Epidemiology of Diabetes and Its Vascular Lesions., ed.[NY]: Elsevier; 1978: 19-39

[2] Diabetes, organización mundial de la salud. 2012; Available in: http://www.who.int/mediacentre/factsheets/fs312/es/

[3] 3.Wilson Rodger, Non- insulin- dependent (type II) diabetes mellitus. 2013; Available in: http://www.ncbi.nlm.nih.gov/pmc/articles/PMC1336077/pdf/cmaj00253-0033.pdf

[4] Thomson \& Thomson, Genética Médica. 7nd Ed. Barcelona, España: Elsevier- Masson; 2007.

[5] International Diabetes Federation [IDF]. ¿Qué es la diabetes 2013; Available in: http://www.idf.org/worlddiabetesday/toolkit/es/gp/que-es-la-diabetes

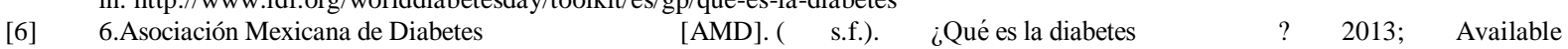
in: http://www.amdiabetes.org/que_es_la_diabetes.php

[7] Pacheco Leal, D. Bioquímica Médica, Limusa, ed. México, 2004.

[8] Día mundial de la diabetes. 2010; available in: http://www.inegi.org.mx/inegi/default.aspx?c=274

[9] 9.Federación internacional de la diabetes. 2012; Available in http://idf.org/diabetesatlas/5e/Update2012

[10] 10.International Diabetes Federation [IDF] Plan mundial contra la diabetes 2011-2021. 2011; Available in: http://www.idf.org/sites/default/files/attachments/GDP-Spanish.pdf

[11] International Diabetes Federation [IDF]. Diabetes Atlas Update 2012; Available in: http://www.idf.org/diabetesatlas/5e/Update2012?language=es

[12] International Diabetes Federation [IDF]. (2013a). Factores de riesgo. Available in: http://www.idf.org/node/26455?language=es

[13] Instituto Nacional de Salud Pública [INSP] y Secretaría de Salud [SSA]. Diabetes Mellitus: la urgencia de reforzar las políticas públicas para su prevención y control . Instituto Nacional de Salud Pública $\quad$ 2012; Available in: http://ensanut.insp.mx/doctos/analiticos/DiabetesMellitus.pdf

[14] Estadística. 2013; Available in: http://www.fmdiabetes.org/fmd/pag/estadisticas.php

[15] Programa de diabetes de Hidalgo. http://salud.edomexico.gob.mx/html/Otros/FORO\%20PARA\%20EL\%20INTERCAMBIO\%20DE\%20EXPERIENCIAS\%20EXIT OSAS $\% 20 \mathrm{EN} \%$

[16] Miller, L. True Bugs: Leaffooted Bugs: Giant Mesquite Bugs (Thasus neocalifornicus. 2009. Recuperado 10 de noviembre, 2013. Available in: http://colinlmiller.com/wildlife/hemiptera/hemiptera_mesquitebugs.htm

[17] Mendoza, M.N. et al. Elaboración de una salsa tradicional del Valle del Mezquital utilizando la chinche del mezquite "xamui" (Thasus gigas) XII CONGRESO NACIONAL DE CIENCIA Y TECNOLOGIA DE ALIMENTOS, Universidad de Guanajuato. 2010; 971-976

[18] Braylovsky, H. Mayorga, C. Ortega L, G. y Barrera, E. Estadios ninfales de los coreidos del Valle de Tehuacan, Puebla, México (Hemiptera-Heteroptera) II. Especies asociadas a huizacheras (Acacia spp.) y Mezquiteras (Prosopis spp): Mozena lunata, Pachylis hector, Savius jurgiosus y Thasus gigas. Annales Inst. Biol UNAM Ser. Zool 1995; 66 Suppl 1: 57-80

[19] Número $\begin{array}{lllll}\text { de } & \text { habitantes. } & \text { Hidalgo. } & \text { INEGI } & \text { 2013; }\end{array}$ http://cuentame.inegi.org.mx/monografias/informacion/Hgo/Poblacion/default.aspx?tema=ME\&e=13

[20] Echavarría Flores M, García Torres ME, Calderón Ordoñez MB, Olvera Luna AG, Ruvalcaba Ledezma JC. The bedbug "Xamuis" (Thasus gigas), a new treatment for diabetes or nutrimental culture. Int. J. Res. Ayurveda Pharm 2013; 4 suppl 6: 881-884 